Zdenka Nanut

Planinšek

Ljudska univerza

Koper

\title{
NOVI VIDIKI SVETOVANJA V IZOBRAŽEVANJU ODRASLIH
}

\section{Svetovanje za prevzemanje odgovornosti in tveganja za osebnostno rast}

času, odkar delam na Ljudski univerzi v Kopru, sem si nabrala že precej znanja in izkušenj v svetovanju. Ugotavljam, da so bili skoraj vsi udeleženci izobraževanja za pridobitev poklicne izobrazbe za odrasle nekoč neuspešni učenci, ki so $\mathrm{v}$ rani mladosti zaradi različnih vzrokov izpadli iz rednega izobraževalnega sistema. V njih sta ostala globok občutek nezadovoljstva in želja biti ter doseči nekaj več. Vsem je skupna šibka samopodoba in močan občutek manjvrednosti.

Ti posamezniki potrebujejo za uresničitev svojih ciljev sprotno pomoč in sodelovanje andragoškega delavca $\mathrm{v}$ vlogi svetovalca. Udeleženci v programu sami izražajo potrebo po svetovanju in tudi statistični podatki in raziskave kažejo na vse večjo pomembnost tovrstnega dela.

Svetovanje postaja del redne dejavnosti vsake izobraževalne institucije, ki izobražuje odrasle. Je nepogrešljivo pri izvajanju andragoškega procesa in marsikdaj celo odločilno za uspeh posameznega udeleženca izobraževanja.

\section{VLOGA SVETOVANJA V IZOBRAŽEVALNEM PROCESU}

Svetovanje $\mathrm{v}$ izobraževanju je proces, $\mathrm{v}$ katerem svetovalec $\mathrm{v}$ nizu pogovorov pomaga svetovancu pri iskanju novih poti, reševanju problemov in negotovosti, ki se porajajo med izobraževanjem. S tem ga usmerja in vodi na poti proti izobrazbenim ciljem.

Vlogo svetovanja v izobraževanju lahko razdelimo na:

- svetovanje pred vključitvijo $\mathrm{v}$ izobraževanje, pri čemer skušamo posamezniku pomagati pri izbiri najustreznejših smeri, oblik in načinov izobraževanja;

- svetovanje med potekom izobraževanja in

- svetovanje po končanem izobraževanju.

Z vključitvijo v proces izobraževanja odraslih se posameznik podaja na novo, izzivov polno, verjetno več let trajajočo pot. Poln je pričakovanj in strahu pred neznanim, še posebej pred morebitnim neuspehom. Izobraževanje zahteva od njega niz dodatnih aktivnosti, ki se jih mora šele priučiti. Navezovanje novih socialnih stikov in opuščanje starih ter oblikovanje novih vzorcev vedenja zahtevata od udeleženca veliko volje in vztrajnosti.

Pri tem so mu lahko v pomoč andragoški de-

V najširšem smislu lahko razumemo svetovanje $v$ izobraževanju kot proces, ki pomaga odraslemu človeku pri njegovem izobraževanju in vzgoji ter $\mathrm{s}$ tem pri oblikovanju njegove osebnosti, da bi lahko zadovoljivo opravljal funkcije odrasle osebe (Jelenc, 1982). 
lavci, ki spremljajo njegovo izobraževanje. S primernim svetovanjem mu lahko pomagajo premagovati težave.

Svetovanje med izobraževanjem ima dva temeljna cilja (UDACE - Unit for the Development of Adult Continuing Education):

- pomoč udeležencu izobraževanja pri organiziranju učenja;

- pomoč pri odpravljanju različnih težav, ki ovirajo njegovo izobraževanje (negativne izkušnje pri dosedanjem izobraževanju, strah pred neuspehom, socialne in družinske razmere, finančna sredstva, oddaljenost od kraja izobraževanja idr.).

Svetovanje, opisano pod prvo točko, je v večini izobraževalnih institucij že utečeno. Udeležence učimo $\mathrm{v}$ individualnih pogovorih ali v skupinskih konzultacijah tehnik učenja, svetujemo jim $\mathrm{v}$ zvezi $\mathrm{z}$ njihovimi učnimi nagnjenji, pri oblikovanju učnih ciljev in jih naučimo tehnik sproščanja ter koncentracije. S svetovanjem jim hkrati vlivamo zaupanje $\mathrm{v}$ njihove sposobnosti in utrjujemo motivacijo za nadaljnje učenje.

Za tovrstno svetovalno delo imamo andragoški delavci in organizatorji izobraževanja dovolj znanja in kompetenc.

\section{(PRE)OBLIKOVANJE IDENTITETE IN POMEN SVETOVANJA}

Problemi pri pridobivanju novega znanja, ki ga udeleženci potrebujejo za pridobitev izobrazbe, niso edini, s katerimi se srečujejo odrasli učenci med izobraževanjem.

Rada bi opozorila na dogajanja in procese, ki na videz niso neposredno povezani $z$ izobraževanjem, so pa neizogiben spremljevalec vzgojne komponente izobraževalnega procesa.

Ugotovila sem, da se med šolanjem posamezniki zelo spreminjajo. $\mathrm{V}$ trenutku, ko prevzamejo dodatno odgovornost - izobraževa-

nje, se njihovo življenje zelo spremeni. Porušijo se stari vzorci vedenja in prisiljeni so reorganizirati sebe ter svoje življenje. To sproži v njihovi osebnosti in okolici dodatne težko obvladljive probleme in konflikte.

Pri ljudeh, ki se pri nas šolajo že dalj časa, sem opazila bistvene, kvalitativne spremembe v njihovi osebnosti. Ne spremeni se samo njihova zunanjost, ki se kaže predvsem $v$ drugačnem zunanjem videzu in načinu oblačenja, temveč se bistveno spremeni tudi njihov nastop. Marsikdaj sem imela občutek, da gre za drugo osebo, ne pa za

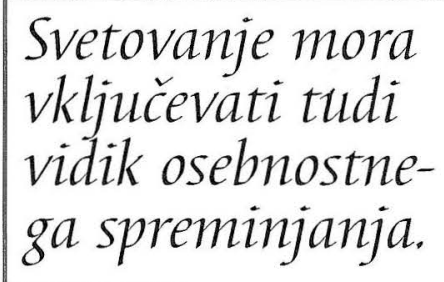
tisto, ki se je pred leti prvič oglasila pri nas in prosila za nasvet glede šolanja.

Vključitev odraslega posameznika v izobraževanje močno vpliva na njegovo socialno in osebno identiteto, kajti ne kaže pozabiti, da se predstava odraslega o sebi oblikuje predvsem na podlagi:

- odnosov z drugimi ljudmi in

- dosežkov, pridobljenih z delom.

Oblikovanje samopodobe odraslega je torej proces vzajemnega vplivanja ter delovanja posameznika in njegovega ožjega socialnega okolja.

Še pred štiridesetimi leti je veljalo v psihologiji prepričanje, da se osebnostna struktura oblikuje nekako do konca obdobja adolescence. $\mathrm{V}$ tem času naj bi se posameznik obliko-

$Z$ vključitvijo v izobraževalni proces se korenito spremeni delovanje posameznika, ki prevzame novo vlogo - vlogo učenca, razširi in spremeni pa se tudi njegovo socialno okolje, saj je razred na novo oblikovana socialna struktura, v kateri se želi ta uveljaviti. Sprememba posameznikovega načina delovanja in življenja zato sproži intenziven razvoj osebnosti oziroma pospeši njegovo osebnostno rast. 


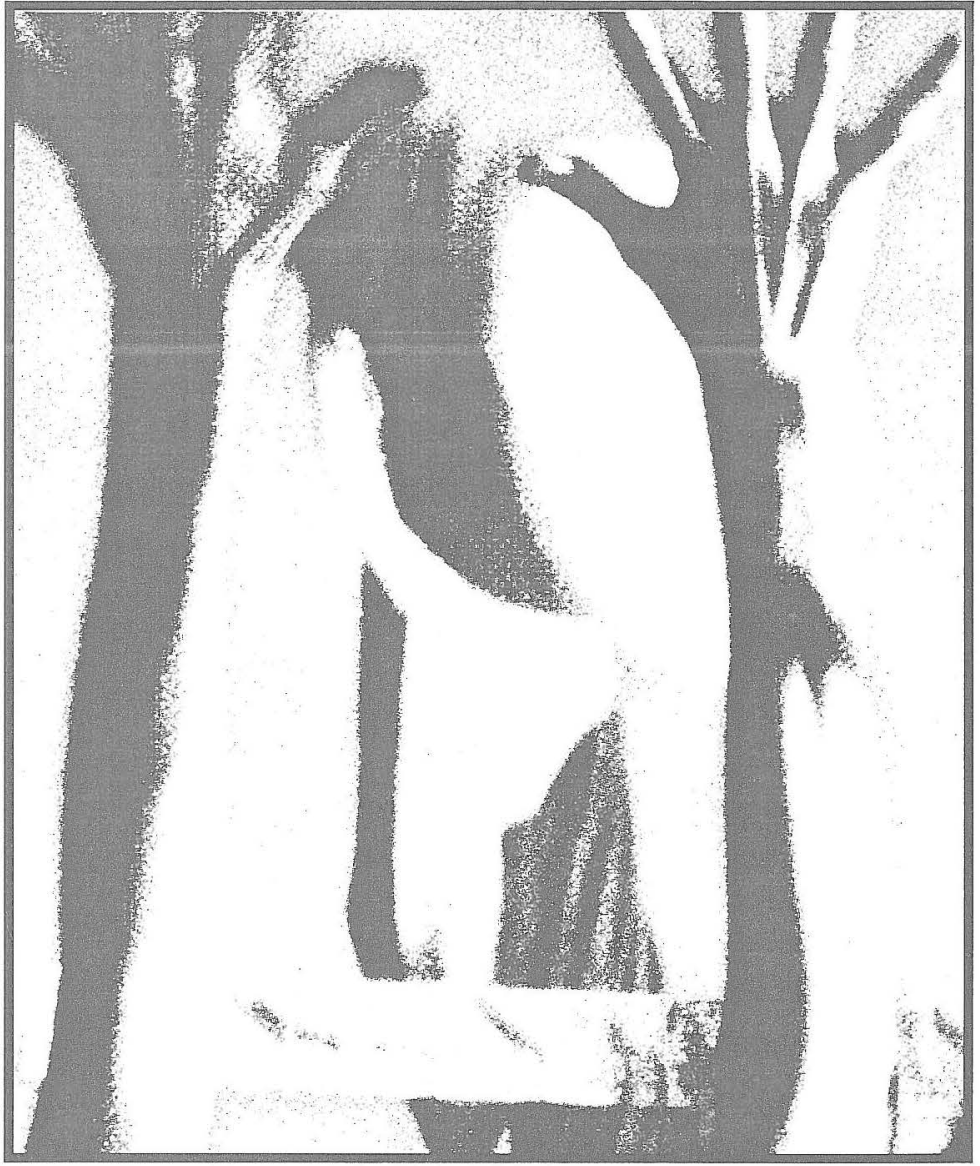

val $\mathrm{v}$ razmeroma trajno in edinstveno celoto psihofizičnih lastnosti. Posameznik, ki je dozorel $\mathrm{v}$ tem smislu, ima jasno osebno identiteto, vendar to ni pravilo, ki bi veljalo za vse. Osebe, s katerimi se srečujem pri svojem delu, namreč niso uspešno rešile krize iskanja lastne identitete $\mathrm{v}$ času adolescence.

Čeprav so to biološko zrele osebe, se socialna in duhovna raven njihove osebnosti pod vplivom samodejavnosti, $v$ našem primeru povezane $\mathrm{s}$ procesom izobraževanja, še vedno spreminja. Spreminjajo in na novo oblikujejo se predvsem lastnosti, ki so razvojno najbolj podvržene vplivom socialnega okolja in samoaktivnosti, to so značajske lastnosti in predvsem dinamične komponente osebnosti. znanjem se najopazneje spreminjajo stališča,

etične in moralne vrednote, krepi se motivacija, pojavlja se novo znanje. To pripomore $\mathrm{k}$ posameznikovi drugačni in boljši samopodobi.

Z izobraževanjem kot dodatno aktivnostjo človek bolje zadovoljuje osnovne potrebe po svoji samouresničitvi in psihosocialni stabilnosti. $Z$ dobrimi odnosi v razredu se krepi občutek pripadnosti in sprejetosti, z novimi prijateljstvi je zadovoljena potreba po ljubezni, uspeh pri učenju jim daje občutek moči, $z$ upoštevanjem osnovnih andragoških načel pri poučevanju se krepi občutek svobode. Vse to pripomore k občutku zadovoljstva udeleženca izobraževanja s samim seboj in posredno tudi s svojo okolico.

$\mathrm{Z}$ osebnostno spremembo se spremeni tudi posameznikov zunanji svet. Ljudje nenehno opredeljujemo zunanje informacije in jih razčlenjujemo glede na predstave ter sheme, $\mathrm{ki}$ smo si jih ustvarili. Tako si svojo stvarnost gradimo in konstruiramo sami.

V šolskem letu 1998/99 sem opravila raziskavo, v kateri sem 65 udeležencev, ki se na Ljudski univerzi v Kopru izobražujejo v programih za pridobitev poklicne izobrazbe že dve ali več let, spraševala o vplivih izobraževalnega procesa na njihovo osebnost in njihov način življenja. Rezultati kažejo, da izobraževanje odraslih kot vzgojno-učni proces pozitivno vpliva na človekovo osebnostno in tudi duhovno rast. Anketiranci so odgovarjali na vprašanja $v$ nestrukturiranem eseju, tako da so napisali le tisto, kar sami opažajo in občutijo. Pri prebiranju njihovih odgovorov sem ugotovila, da imajo pozitivne spremembe $\mathrm{v}$ posameznikovem življenju tudi svojo senčno stran, ki sem jo prej, v pogovorih s posameznimi udeleženci, le redko opazila, saj o njej niso spregovorili naravnost.

Ko se začne posameznikova osebnost opazno spreminjati, čeprav na boljše, občutijo tisti, ki z njim živijo, spremembo kot negativno motnjo. Predvsem je ogrožen njihov občutek var- 
nosti, saj je razmerje postalo za njih drugačno in nepredvidljivo. Veliko potrpljenja in razumevanja je potrebno, da damo sočloveku čas in možnost, da te spremembe sprejme, da uvidi tudi njihovo pozitivno stran in da se nanje navadi. Posameznik, ki se izobražuje ima poleg objektivnih težav pri preseganju samega sebe še dodatne težave, ki zelo otežujejo njegov napredek. O tem pripovedujejo predvsem ženske. Otroci se pritožujejo, ker »premalo« naredijo zanje, mož sitnari, ker ne posvečajo več toliko časa gospodinjstvu in njemu, vmešava se tudi mati in skuša ohraniti nadzor nad že odraslo hčerko ipd. Posebno hudo pa je, kadar človek med izobraževanjem s svojo intenzivno osebnostno rastjo preraste svojega partnerja. »Nimava se več kaj pogovarjati,« izjavlja neka udeleženka, »in bojim se, da je za reševanje zakona že prepozno.« $\mathrm{Na}$ take spremembe so ljudje, ki se odločajo za izobraževanje, najmanj pripravljeni, zato taki in podobni problemi velikokrat usodno vplivajo na udeležence $v$ izobraževanju.

Dobri medčloveški odnosi so temeljni pogoj za posameznikovo srečo in njegov uspeh, vendar marsikdo ne najde sam poti iz krize. Večina ni sposobna niti identificirati problema. Krivdo za nastale probleme iščejo pri sebi, $v$ poskusih reševanja in razumevanja problemov pa izgubljajo dragoceno življenjsko energijo, kar jim jemlje moč in čas, ki bi ju potrebovali za doseganje učnih ciljev. Tudi posamezniki, ki se srečujejo s takimi problemi, večkrat ne iščejo pomoči, saj ne vidijo neposredne povezave med poslabšanjem med-

Svetovalno delo je v Sloveniji premalo razvito, da bi lahko pomagali vsem, ki potrebujejo pomoč. Organizacije za svetovanje niso povezane med sabo, strokovnim delavcem $v$ izobraževanju odraslih pa marsikdaj manjka ustreznega znanja, spretnosti in izkušenj za reševanje problemov udeležencev izobraževanja. sebojnih odnosov $v$ njihovem ožjem socialnem okolju in procesom izobraževanja, v katerega so vključeni.

Da bi ugotovila bistvo opisanega problema, sem v letošnjem šolskem letu vprašala udeležence, ki so prišli k meni, da bi prenehali šolanje in se izpisali iz programa, o tem, kaj menijo o njihovi nameri njihovi najbližji. To vprašanje jih je spodbudilo, da so začeli govoriti o medosebnih odnosih. Veliko jih je priznalo, da njihovi najbližji sicer nimajo nič proti, da se izobražujejo, vendar niso zadovoljni $\mathrm{z}$ drugačnim načinom življenja. Želeli bi, da bi ostalo vse tako
Spremembe osebnosti pogosto vodijo k porušenju ravnotežja $v$ partnerskem razmerju. kot prej, čeprav so $\mathrm{z}$ vključitvijo $\mathrm{v}$ program prevzeli dodatno obveznost.

Institucije, ki izobražujejo odrasle, bi morale odpreti svoja vrata tudi njihovim ožjim družinskim članom. Že na uvodne pogovore, na katerih svetujemo bodočim udeležencem izobraževanja, lahko povabimo tudi njihove partnerje, otroke ali starše, da bodo imeli tudi oni občutek, da sodelujejo pri pomembni odločitvi. Vrata bi morala biti odprta tudi pri razrednih urah, ko rešujemo običajne težave z izobraževanjem, družinski člani naj bodo zraven na pogovoru s strokovnim delavcem in ne pozabimo jih povabiti na podelitev spričeval.

Pri svetovalnem delu v izobraževanju odraslih se torej ne ukvarjajmo le $\mathrm{z}$ udeleženci izobraževanja, temveč posredno tudi z njihovimi ožjimi družinskimi člani, če hočemo, da bo svetovanje res učinkovito.

\section{LITERATURA}

Z. Jelenc, Svetovalno delo pri vzgoji in izobraževanju odraslih, Dopisna delavska univerza Univerzum, Ljubljana, 1982: 64 .

The Challenge of Change, Developing Educational Guidance for Adults, Leicester, 1988. 